University of Nebraska - Lincoln

DigitalCommons@University of Nebraska - Lincoln

Transactions of the Nebraska Academy of

Sciences and Affiliated Societies

Nebraska Academy of Sciences

Summer 8-18-2020

\title{
Characteristics of a River Otter (Lontra canadensis) Maternal Den in the Central Platte River Valley, NE
}

Jenna M. Malzahn

Platte River Whooping Crane Maintenance Trust, jmalzahn@cranetrust.org

Andrew J. Caven

Platte River Whooping Crane Maintenance Trust, acaven@cranetrust.org

Joshua D. Wiese

Platte River Whooping Crane Maintenance Trust, jwiese@cranetrust.org

Follow this and additional works at: https://digitalcommons.unl.edu/tnas

Part of the Aquaculture and Fisheries Commons, and the Behavior and Ethology Commons

Malzahn, Jenna M.; Caven, Andrew J.; and Wiese, Joshua D., "Characteristics of a River Otter (Lontra canadensis) Maternal Den in the Central Platte River Valley, NE" (2020). Transactions of the Nebraska Academy of Sciences and Affiliated Societies. 526.

https://digitalcommons.unl.edu/tnas/526

This Article is brought to you for free and open access by the Nebraska Academy of Sciences at DigitalCommons@University of Nebraska - Lincoln. It has been accepted for inclusion in Transactions of the Nebraska Academy of Sciences and Affiliated Societies by an authorized administrator of DigitalCommons@University of Nebraska - Lincoln. 


\title{
Characteristics of a River Otter (Lontra canadensis) Maternal Den in the Central Platte River Valley, NE
}

\author{
Jenna Malzahn, ${ }^{1 *}$ Andrew J. Caven, ${ }^{1}$ and Joshua D. Wiese ${ }^{1}$ \\ 1 Platte River Whooping Crane Maintenance Trust, Wood River, NE 68883; \\ (JM) jmalzahn@cranetrust.org, (AJC) acaven@cranetrust.org, (JDW) jwiese@cranetrust.org \\ *Corresponding author: Jenna Malzahn, jmalzahn@cranetrust.org; (248)-914-0073
}

\begin{abstract}
River otters (Lontra canadensis) encompass a broad geographic range including coastal, riverine, and lacustrine systems. However, knowledge of reproductive behavior and structural den characteristics remain relatively few in the literature, particularly in the Great Plains. Distinctions between the terms "den", "den site", "natal den", and "maternal den" are often ambiguous, obscuring our understanding of river otter's young-rearing behavior. We used observations and descriptions regarding a single maternal den site and a broad reading of the mustelid literature to propose a more standardized maternal den definition for river otters and specify hypotheses for future research. From 25 April to 13 May 2019 and from 4 April to 30 April 2020, we recorded observations of parental behavior, such as relocation of young to a maternal den and aquatic acclimation, via direct or video surveillance. We also systematically assessed habitat and site characteristics associated with this maternal den. We estimated that the river otter young were relocated to the maternal den between 6 to 8 weeks of age, placing them at 8 to 10 weeks at the time of their first observed aquatic acclimation. The maternal den consisted of a distorted metal pipe (entrance $=9 \mathrm{~cm}$ height, $28 \mathrm{~cm}$ width) on the bank of an excavated perennial pond within $100 \mathrm{~m}$ of multiple anthropogenic structures (i.e. cottage, office), but considerable distance from the Platte River $(441 \mathrm{~m})$. The maternal den was located adjacent to a small pond (length $=66.4 \mathrm{~m}, \mathrm{width}=15.2 \mathrm{~m}, \mathrm{max}$ depth $=69$ $\mathrm{cm})$ on a moderate bank slope $(29.5 \%)$ in relatively dense herbaceous $(\overline{\mathrm{x}}$ cover $=55.0 \%, \overline{\mathrm{x}}$ height $=0.53 \mathrm{~m})$ and woody $(\overline{\mathrm{x}}$ cover $=$ $37.5 \%, \bar{x}$ height $=1.56 \mathrm{~m}$ ) understory vegetation. We suggest that this unique site may have provided a number of benefits including thermoregulatory advantage, predator protection, relatively stable water depth, and proximate access to resources. We suggest that river otter maternal dens are sites used subsequent to and exclusive of parturition that proceed weaning where females continue to exhibit denning behavior as young are still largely dependent and in the earliest stages of developing motor and survival skills. We hypothesize that a set of interrelated factors distinct to particular juvenile life stages promotes maternal den site selection. This represents the first detailed description of a river otter maternal den and den site reuse in the Central Platte River Valley (CPRV), Nebraska and a rare description from the Great Plains.
\end{abstract}

Keywords: River Otter, Semi-Aquatic Mammal, Maternal Den, Den Site, Den Relocation, Central Platte River Valley, Great Plains, Natural History, Anthropogenic Habitat

DOI: $10.32873 /$ unl.dc.tnas.40.5

\section{Introduction}

The North American river otter (Lontra canadensis) is a semiaquatic mammal with an extensive distribution across both marine and freshwater environments (Gorman et al. 2006, Reed-Smith 2012). Frequent documentation by early explorers on the Missouri and Platte rivers suggests a robust historic population (Jones 1964). However, unregulated harvest and habitat degradation, resulting from pollution and agricultural conversion, led to the extirpation of the species from the state of Nebraska by the early 1900s (Farney and Jones 1978, Melquist and Hornocker 1983, Biscof 2006, Wilson 2012). Due to extensive reintroduction efforts by the Nebraska Game and Parks, between 1986 and 1991, the current range of river otters in Nebraska now closely reflects historic distributional records (Bieber et al. 2018, Panella and Wilson 2018). Identified core areas of activity include the Platte, Elkhorn, central and eastern Niobrara, and southern Loop rivers as well as nearby lacustrine and palustrine wetland systems (Wilson 2012, Panella and Wilson 2018). Evidence suggests there is once again a healthy, reproductively viable, and expanding population of river otters in the state (Panella and Wilson 2018, Schneider et al. 2018).

Lacking the physiological adaptations to indefinitely stay in water, this species depends on terrestrial shelters, especially during the reproductive season (Melquist and Dronkert 1987, Pikora 2016). Previously recorded reproductive denning sites include burrows created by 
other species, natural formations, and other features on the landscape (Liers 1951, Melquist and Hornocker 1983, Woolington 1984, Dronkert-Egnew 1991, Reid et al. 1994, Gorman et al. 2006). Despite references that river otters use multiple dens during the reproductive season (Liers 1951, Woolington 1984, Dronkert-Egnew 1991, Reid et al. 1994, Reed-Smith 2012), descriptions from the literature are limited. Gorman et al. (2006) speculated that the energetic demands of traveling to forage combined with relocating young to new dens would outweigh any potential benefits, while Durbin (1996) observed a family of Eurasian otters (Lutra lutra) using a total of 14 dens during the 12 weeks following parturition.

Lacking precise use of the terms den, den site, natal den, and maternal den in the literature obscures understanding of river otter young-rearing behavior and densite selection. The importance of discrimination between the terms natal and maternal den is displayed in previous studies on the American marten (Martes americana; Ruggiero et al. 1998), wolverine (Gulo gulo; Magoun and Copeland 1998), and fisher (Pekania pennanti; Powell et al. 1997, Green 2017), where these distinctions were significant for understanding species recruitment patterns and characteristics associated with appropriate denning sites. Natal dens are defined as parturition sites, whereas maternal dens are defined as sites that proceed weaning and are subsequent to and exclusive of parturition (Magoun and Copeland 1998, Ruggiero et al. 1998, Green 2017). Considering this species' large, disparate geographic range, more information is needed to understand river otter behavior during the reproductive season. In this report we discuss observations of rearing behavior and den site reuse as well as provide the first detailed description of structural and site characteristics of a river otter's maternal den in the Central Platte River Valley (CPRV), Nebraska. Then using a combination of our observations with the river otter reproductive denning literature and a broad reading of the mustelid literature, we further clarify the ecological characteristics and potential biological functions of natal and maternal dens.

\section{Methods}

\section{Behavioral Observations}

On 25 April 2019, we detected and photo-documented behavioral observations of a river otter from a distance of 50 to $250 \mathrm{~m}$, using binoculars (10x42) and a Nikon CoolPix B500 camera (Tokyo, Japan) for a total of 120 minutes. On 26 April 2019, we set one remote camera trap (Wildgame Innovations 10B38D2, Grand Prairie, TX, USA) $5 \mathrm{~m}$ away from the den entrance and another remote camera trap (Browning Command Ops BTC-4, Morgan, UT) within $2 \mathrm{~m}$ of a wildlife trail that led to the den. We removed both remote camera traps on 30 April 2019 due to low detection rates and concerns with disturbance. On 30 April 2019, an AXIS P5534-E (Lund, Sweden) portable live-streaming camera with $36.0 x$ (2.0x D) zoom was set across the pond about $28 \mathrm{~m}$ from the den entrance for easier, less invasive observation. ReedSmith (2012) was used to interpret river otter behavior from $90 \mathrm{~min}$ of footage recorded near the den and surrounding pond site from 30 April to 13 May 2019. To determine site reuse, we set two remote camera traps (Moultrie M-50i MCG-13270, Calera, AL, USA) at a distance of 1 and $3 \mathrm{~m}$ away from the den entrance to record $10 \mathrm{sec}$ videos from 28 February to 12 May 2020. The development stages and age of young otters were determined using Liers (1951), Lariviere and Walton (1998), Reed-Smith (2012) and Smithsonian (2019).

Through 22 systematic searches, from 1 February to 1 June 2019, and 33 systematic searches from 1 February to 1 June 2020, we documented river otter sign through sightings, tracks, and scat in the two perennial ponds $\left(40.787270^{\circ} \mathrm{N},-98.464853^{\circ} \mathrm{W} ; 40.787575^{\circ} \mathrm{N},-98.463719^{\circ} \mathrm{W}\right)$ near the Crane Trust main office $\left(40.787532^{\circ} \mathrm{N}\right.$, $\left.-98.465343^{\circ} \mathrm{W}\right)$, including the pond where the maternal den was located.

\section{Den Site Assessment}

We recorded habitat measurements of the maternal den on 22 May 2019, including measurements of the width and height of the entrance, depth and length of the den, wetland bank slope, and elevation via a Global Positioning System (GPS 73, Garmin Ltd., Lenexa, KS). We estimated distances to surrounding habitat features using Google Earth Pro for more distant and larger features (i.e., distance to river) and a laser rangefinder for smaller and closer features (i.e., distance to woodland; Nikon Laser $8006 \times 216.0^{\circ}$, Tokyo, Japan). The depth profile of the adjacent pond was estimated by sampling the distance from the water's surface to the bottom's substrate along two perpendicular transects every 2 meters from bank to bank. Total cover estimates for the dominant 3 vascular plant species, total woody and herbaceous cover, bare ground and litter cover, and median woody and herbaceous vegetation height estimates were recorded within $1.0 \mathrm{~m}$ by 0.5 $\mathrm{m}$ quadrats placed in each cardinal direction adjacent to the den (quadrats started just at the edge of the den opening) (Daubenmire 1959, Symstad et al. 2008). This method allows for overlapping canopies of vegetative cover (i.e., woody cover above herbaceous, etc.); therefore, cover estimates may exceed 100\% (Daubenmire 1959, Symstad et al. 2008). We collected discharge and gage height data for the USGS 06770500 Platte River near Grand Island, NE from U.S. Geological Survey (2016). 


\section{Results}

\section{Behavior Observations}

On 25 April 2019 from 16:31 PM to 18:20 PM, an adult female river otter was discovered relocating young to a maternal den location in an off-channel habitat in the CPRV. The adult river otter, presumed the mother as females are solely responsible for the care of the litter, was observed carrying young by the scruff of their neck on three separate occasions. A variety of habitats, including lowland tallgrass prairie, a mowed lawn, a paved road, a shallow marsh, and an open-water pond were traversed during the relocation of young to the maternal den. The natal den location was at least $250 \mathrm{~m}$ from the maternal den based on the female's behavior. The exact path was largely obscured by vegetation and crossed a prairie inhabited by bison (Bison bison). Concern of disrupting the relocation process limited other methods of investigation. Comparative body length and mobility observations suggest young to be between 6 and 8 weeks old (Liers 1951, Lariviere and Walton 1998, Reed-Smith 2012, Smithsonian Institute 2019). Average time between trips was $25 \mathrm{~min}$, however during the interim of transporting young 2 and 3, the female was observed fishing in an adjacent pond for
$14 \mathrm{~min}$. Hunting was focused along the vegetated edges of the pond where the female successfully depredated a fish. Visual assessment at a distance $(\sim 30 \mathrm{~m})$ and habitat use suggested the fish may have been a Lepomis sp. or a Perciformes sp. Previous photo-documented observations, from March 2019 and March and April 2020, from this site support this assessment as staff biologists documented an adult river otter predating upon channel catfish (Ictalurus punctatus) and bluegill (Lepomis macrochirus).

On 6 May 2019, the female was detected leaving the den at 10:35 AM. Two days later on 8 May 2019, two young otters were seen at the den entrance at 13:56 PM, and from 16:36 PM to 17:01 PM, four young were observed climbing along the bank and swimming independently in shallow water near the den (Figure 1). The female remained alert, presumably for potential predators or to tend to her young, during the time before the family re-entered the den, where one young was picked up by the scruff and dragged into the den. The entire family was again detected on 9 May 2019 at 12:21 PM for 15 min swimming and climbing along the bank, while the female was observed bringing nearby vegetation into the den as suspected denning material. At 15:56 PM, the

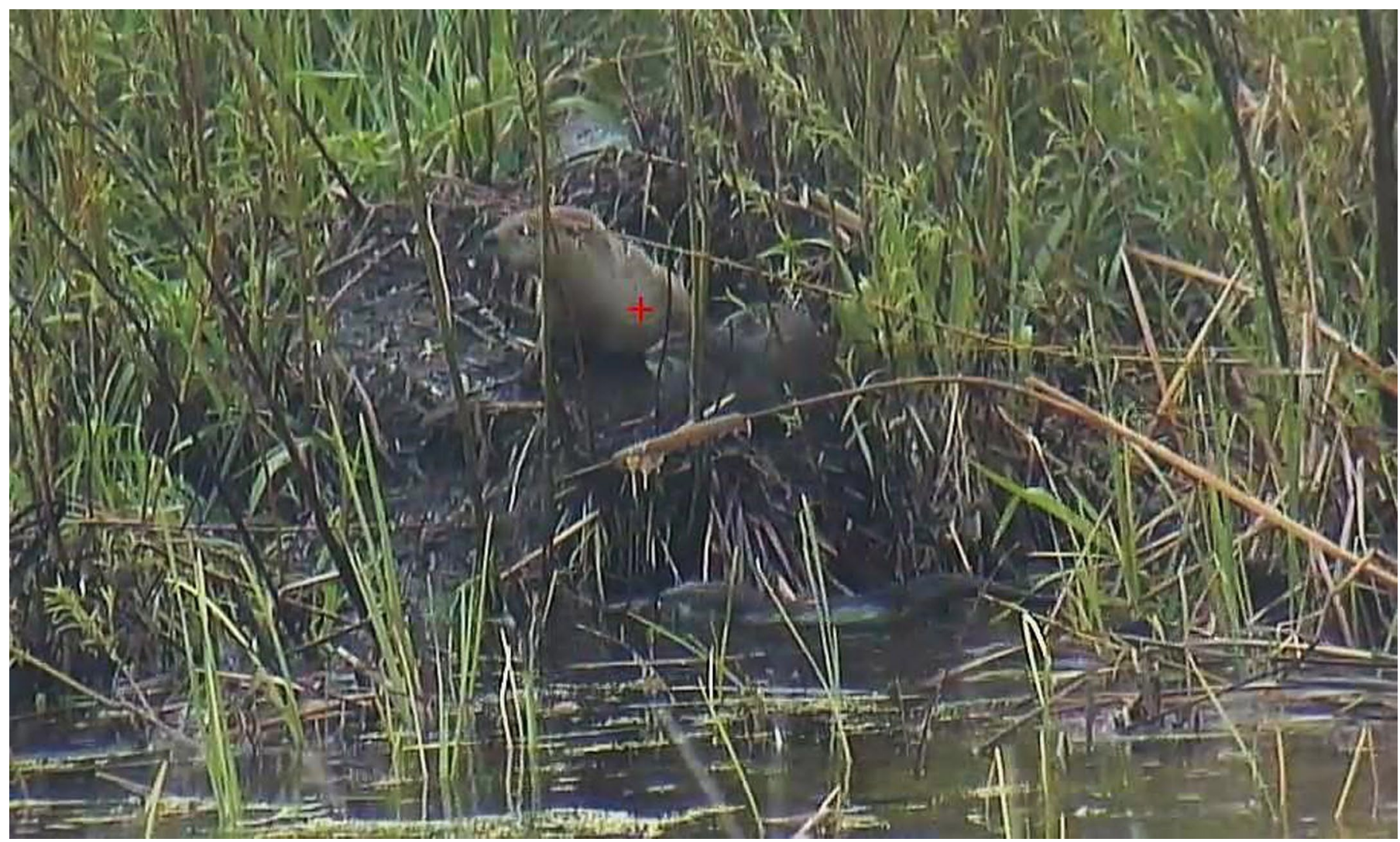

Figure 1. Maternal den with female river otter (Lontra canadensis) and two young visible at entrance and in pond on 8 May 2019 in the Central Platte River Valley Nebraska, USA. Screenshot of video taken 10 December 2019 by Jenna Malzahn. 
entire family was again observed for 25 min swimming and climbing along the bank. The last observations were recorded on 13 May 2019 at 8:03 AM for $30 \mathrm{~min}$, where the family swam farther away from the den than previously observed, and at 15:20 PM for $5 \mathrm{~min}$, three young were visible climbing around the den. We checked the den on 17 May 2019 and 29 May 2019 and there was no evidence of either the female or young at or near the den on both occasions. On the latter date, the water level had risen and the den was flooded.

We first detected den site activity at 7:02 AM on 1 March 2020, with an adult otter observed exiting the den. Reuse of the metal pipe as a maternal den was not observed until 4 April 2020 at 13:27 PM when the female otter was discovered relocating young to this den. We observed similar behaviors to 2019, including gathering of denning material, climbing around the den, and aquatic acclimation. This female otter and her three young resided in this den until leaving on 30 April 2020 at 14:14 PM.

River otter sightings in nearby habitats resulted in detections for a total of 13 of 22 days (59\%) in 2019, with 1 day $(4.5 \%)$ of observations of multiple adults and 4 days $(18 \%)$ with observations of the female with young, and for a total of 19 of 33 days (58\%) in 2020. River otter tracks were recorded on 2 days ( $9 \%$ ) and river otter scat was recorded on 1 day (4.5\%) in 2019 as well.

\section{Den Site Observations}

The maternal den was located on the bank of a perennial pond $(\ell=66.4 \mathrm{~m} ; w=15.2 \mathrm{~m} ; \bar{x}$ depth $=42.6 \mathrm{~cm}, S D$ $=12.9, n=40$, minimum $=13 \mathrm{~cm}$, max. $=69 \mathrm{~cm}$ ), which at high water levels becomes hydrologically connected to a larger perennial pond about $21.4 \mathrm{~m}$ to the west (Figure 2). These two ponds represent excavations in what was historically a wet meadow (Brei and Bishop 2008). Ponds excavated for sand and gravel extraction, as well as smaller ponds excavated for recreation are common within the CPRV (Pauley et al. 2018). These two ponds are connected via an $18.3 \mathrm{~m} \times 0.3 \mathrm{~m} \times 0.3 \mathrm{~m}(60 \mathrm{ft} \times 1 \mathrm{ft} \times$ $1 \mathrm{ft}$ ) metal pipe that the female otter used as her maternal den (Figure 2). However, only one end of the pipe was accessible for use as the other end was blocked by a water control structure. The end of the pipe that was used as the den entrance was distorted, creating a smaller entrance $(h=9 \mathrm{~cm} ; w=28 \mathrm{~cm})$. The den was located on a relatively gradual slope $(m=29.51 \%)$ with an easterly aspect $\left(76^{\circ}\right)$ and an elevation of $579 \mathrm{~m}$. Located closely to a perennial pond $($ dist. $=91 \mathrm{~cm})$, the den was situated near a cottage, dormitory, and office (dist. $=29 \mathrm{~m}, 76 \mathrm{~m}, 99 \mathrm{~m}$, respectively) as well, but far from the Platte River (dist. $=$ $441 \mathrm{~m}$ ). Den measurements and distances to nearby structures remained constant in 2020. Six river otter scats were detected within $2 \mathrm{~m}$ of the den entrance in 2019, with 4 scats detected in 2020.

Dominant vascular plant species surrounding the den included creeping meadow foxtail (Alopecurus arundinaceus), coyote willow (Salix exigua), goldenrod species (Solidago gigantean \& S. canadensis), reed canarygrass (Phalaris arundinacea), and roughleaf dogwood (Cornus drummondii), which respectively comprised $33.8 \pm 16.5 \%$, $32.5 \pm 17.1 \%, 3.8 \pm 4.8 \%, 3.8 \pm 7.5 \%$, and $2.5 \pm 5 \%$ cover across 4 quadrat samples $(\bar{x} \pm S D)$. Structurally, bare ground accounted for $20.0 \pm 33.7 \%$, litter $8.8 \pm 8.5 \%$, combined herbaceous $55.0 \pm 32.4 \%$, and combined woody $37.5 \pm 18.5 \%$ cover across 4 quadrat samples. Median woody vegetation height per quadrat averaged $156.3 \pm 20.6 \mathrm{~cm}(\mathrm{~min} .=130.0$, max. $=175.0)$ and median herbaceous vegetation height averaged $52.5 \pm 21.2 \mathrm{~cm}(\min .=20, \max .=70)$. The pond's shallow banks and wetland edges supported a host of additional wetland plants including bald spikerush (Eleocharis erythropoda), American speedwell (Veronica americana), narrowleaf cattail (Typha angustifolia), duckweed (Lemna spp.), and swamp milkweed (Asclepias incarnata) (identification using Kaul et al. 2006). The surrounding uplands were dominated by smooth brome (Bromus inermis) and common milkweed (Asclepias syriaca). The

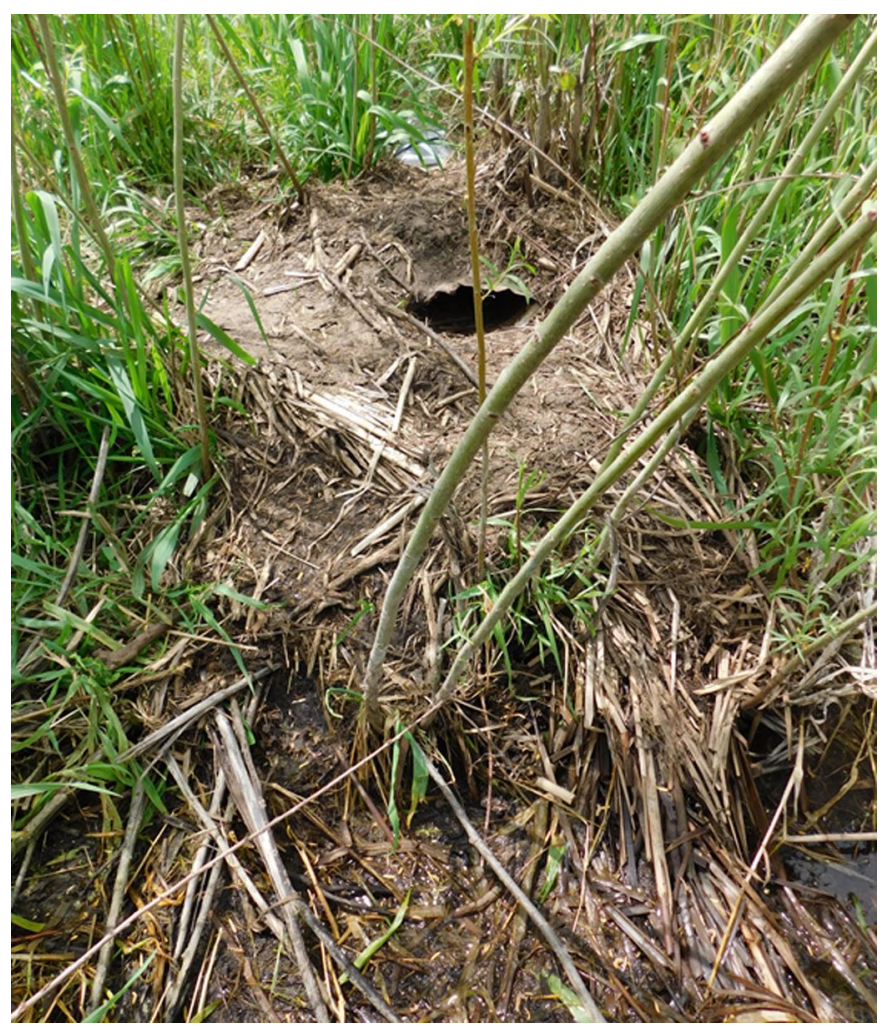

Figure 2. Abandoned maternal den on shore of perennial pond in the Central Platte River Valley Nebraska, USA. Photo taken 22 May 2019 by Jenna Malzahn. 
pond was excavated from and is currently surrounded by Platte-Bolent complex soils, which are occasionally flooded (USDA-NRCS 2019). Based on U.S. Geological Survey (2016), discharge of the Platte River varied between $\sim 1,800$ to $\sim 3,000$ cubic $\mathrm{ft}$ per sec. and gage height fluctuated between $\sim 3.95$ and $\sim 4.45 \mathrm{ft}$ from 25 April to 16 May 2019. During 17 May and 29 May 2019, around time of den abandonment, the discharge of the Platte River varied between $\sim 1,000$ to $\sim 8,000$ cubic $\mathrm{ft}$ per sec and gage height fluctuated between $\sim 3.7$ and $\sim 6 \mathrm{ft}$ (U.S. Geological Survey 2016). Discharge of the Platte River from 4 April to 30 April 2020 varied between $\sim 2,800$ to $\sim 3,700$ cubic $\mathrm{ft}$ per sec and gage height fluctuated between $\sim 4.3$ to $\sim 4.55$ $\mathrm{ft}$, with both these discharge and gage height ranges remaining comparable during the time of den abandonment (U.S. Geological Survey 2016).

\section{Discussion}

\section{Den Structure Characteristics}

Previously recorded river otter natal dens include burrows created by different species [e.g. red fox (Vulpes vulpes), woodchuck (Marmota monax), beaver (Castor canadensis)], natural formations (e.g. cavity in rocks or limestone bluff), and other features (e.g. brush pile, decomposed stump mound, vegetation) (Liers 1951, Melquist and Hornocker 1983, Woolington 1984, Dronkert-Egnew 1991, Reid et al. 1994, Gorman et al. 2006). Characteristic structures of river otter maternal dens include muskrat or beaver bank dens, decomposed stump mounds, and beaver lodges near water (Liers 1951, Woolington 1984, Reid et al. 1994). The selected den by the female in our report consisted of a metal pipe within the bank of an excavated perennial pond. The distorted end of this pipe created a small entrance similar in size to the maternal den measurement recorded by Woolington (1984; 10 to $15 \mathrm{~cm}$ diameter). Natal den entrances studied by Gorman et al. (2006) show an even larger range in openings $(\bar{x}$ height $=43 \mathrm{~cm}, \mathrm{SE}=12 \mathrm{~cm} ; \bar{x}$ width $=67 \mathrm{~cm}, \mathrm{SE}=17 \mathrm{~cm}$ ). The existing literature, for both natal and maternal dens, in addition to our observations suggests that $10 \mathrm{~cm}$ height and $10 \mathrm{~cm}$ width may be potential minimums, with the largest openings recorded in the literature being $135 \mathrm{~cm}$ by $90 \mathrm{~cm}$ (Woolington 1984, Gorman et al. 2006). Our results suggest that the den documented here was near the minimum opening requirements. However, considering the limited data available on river otter den entrances, for both natal and maternal dens, this range may be influenced by regional differences, den availability, or other environmental factors.

The use of a fixed, anthropogenic structure with an entrance near the minimum opening requirements may be beneficial to young as small den entrances are associated with increased insulation, reduced heat loss, and greater thermal buffering within the den (Green 2017). Thermoregulation is necessary for river otter dens as young are vulnerable to environmental extremes, such as temperature change and precipitation events (Gorman et al. 2006). Additional characteristics that provide thermal stability include location below the ground and the addition of vegetation (Dronkert-Egnew1991, Gorman et al. 2006). This behavior, displayed by the female, of filling the den with vegetation has been proposed to aid in temperature regulation and provide good circulation (Dronkert-Egnew 1991). The use of this metal pipe may provide additional benefits of restricting moisture within the den and conferring a greater thermoregulatory advantage as metal is a good conductor of heat. Considering water requires more energy to heat than air, a close proximity to water may require additional features to aid in temperature regulation for river otter young within the den (Weast 1972).

As predation events typically involve young, reproductive dens are often selected to provide protection from predators as well (Liers 1951, Melquist and Hornocker 1983, Woolington 1984, Gorman et al. 2006). Documented river otter predators native to Nebraska include bald eagles (Haliaeetus leucocephalus), coyotes (Canis lantrans), red foxes, bobcats (Lynx rufus), and mountain lions (Puma concolor) (Wilson 2012). Considering the vulnerability of young during the first 6 to 8 weeks, location within the metal pipe may increase stability and security of the den as predators will be unable to create new or enlarge existing openings to predate on young (Liers 1951, Melquist and Hornocker 1983). The location of dens may afford additional protection from predators, as Magoun and Copeland (1998) proposed that, for wolverines (Gulo gulo), dens are generally located in areas with relatively low populations of predators compared to other areas and times of the year. It is possible that the female otter benefited from increased anti-predator effects by denning near a human structure in an otherwise undeveloped landscape. For example, while the coyote can tolerate human environments, the species exists in greater densities in undeveloped grasslands (Boyle 2006, Kamler and Ballard 2006). The maternal den site location may also suggest a lack of appropriate burrows and natural formations for denning.

\section{Den Site Characteristics}

Natal dens are often distant, either vertically or horizontally, from major waterways to protect from frequent flooding and high flows (Woolington 1984, Dronkert-Egnew 1991, Reid et al. 1994, Gorman et al. 2006, Reed-Smith 2012, Pikora 2016). Gorman et al. (2006) and Pikora (2016) contend that the primary selection preference for natal dens is protection from rapid changes in water levels, 
through slope or water stability. Subsequently, the female's 2019 natal den in our report followed these selective factors with an approximate $650 \mathrm{~m}$ distance from the Platte River. The maternal den exhibits a few similarities to selective preferences of natal dens as well, through a comparatively far, lateral distance to the Platte River (441 $\mathrm{m})$ and a nearby water control mechanism. Three previous records, fitting maternal dens, also similarly describe relocations from natal dens far from water (approximately $0.15-0.5 \mathrm{~km}$ ) to maternal dens within close proximity to stable bodies of water (approximately 0-3 m) (Liers 1951, Woolington 1984, Reid et al. 1994). However, as the CPRV is subirrigated, groundwater levels fluctuate in relation to the Platte River and inundate the surrounding wet meadows, sloughs, and ponds, which may impact the stability of water bodies and denning behavior throughout the season (Currier and Henszey 1996, Dronkert-Egnew 1991, Tiner 2016). For instance, the discharge of the Platte River in the spring of 2019 demonstrated not only high volumes but high fluctuations during the time of maternal den abandonment compared to the time the den was occupied (U.S. Geological Survey 2016). However, relatively low variability in the Platte River discharge during the spring of 2020 resulted in the water level of the pond adjacent to the den site being relatively stable during the maternal denning period. These observations demonstrate that even sites which generally provide stable bodies of water for young rearing may become inundated during high flow events in the CPRV. The gradual slope (29.51\%) and successive flooding of this maternal den may suggest a hierarchical shift in selective preferences between natal and maternal dens. Considering the increased age of young present at maternal dens, threats to young by flooding, due to close proximity to water, may decrease as young obtain finer muscle control and mobility (ReedSmith 2012).

As river otters are altricial at birth with high vulnerability during the first 6 to 8 weeks, the removal of dens from waterways may serve as a form of protection from conspecifics as well (Liers 1951, Melquist and Hornocker 1983, Woolington 1984, Gorman et al. 2006). Due to seasonal increases in testosterone related to mating efforts, as breeding follows parturition, aggression in river otter conspecifics, particularly males, may increase during the reproductive season (Liers 1951, Dronkert-Egnew 1991, Bateman et al. 2009). Green (2017) observed that natal den entrances for fishers were smaller than maternal den entrances; reasoning that difference was potentially due to restricting access of adult male fishers during the mating period. For river otters, Melquist and Dronkert (1987) observed that the location of natal dens were not advertised or disclosed, instead females have been observed vigorously defending dens and young from nearby conspecifics (Reed-Smith 2012). Throughout the reproductive season, adult river otters were detected in nearby habitat to the maternal den on a total of 13 days $(59 \%)$ in 2019, with 1 day $(4.5 \%)$ resulting in an observation of multiple adults, and a total of 19 days (58\%) in 2020. Through remote camera traps, 9 additional detections of juvenile/ adult river otter groups, ranging from 2 to 4 individuals, were recorded at the den entrance and in nearby habitat in 2020. Without identifying markings or tags, the sightings may have consisted of different adult river otters, despite the female's nearby residence. The presence of nearby river otter sign (i.e. trails, tracks, scat) also suggests a discrepancy with the secrecy generally used to describe river otter natal dens (Melquist and Dronkert 1987). Therefore, river otter selection of natal dens, in particular, may necessitate distance from areas of potential overlap (i.e. water sources) (Melquist and Hornocker 1983, Woolington 1984, Dronkert-Egnew 1991). However, this influence may decrease for maternal dens, as compared to natal dens, as estrus only lasts 42 to 46 days (Lariviere and Walton 1998).

River otters select for locations with high vegetative cover, often influencing occurrence and distribution (Jenkins and Burrow 1980, LeBlanc et al. 2007, Gallant et al. 2009). Considering this species is less agile on land, vegetation can provide cover for access to reproductive dens, travel to different water sources, and protection from predators (Jenkins and Burrows 1980, Melquist and Hornocker 1983, Reid et al. 1994, LeBlanc et al. 2007). However, little information is available concerning vegetation surrounding reproductive dens. While this maternal den was located along a densely vegetated shoreline, predominantly composed of herbaceous and woody understory, previously recorded natal dens in Minnesota and Alaska were located in areas with minimal understory and ground cover (Woolington 1984, Gorman et al. 2006). Due to this species' wide range, deviations of vegetative cover around dens may point to regional differences (i.e. plant phenology, available habitat structure) as well as possible functional differences between natal and maternal den selection. As Woolinton (1984) noted a difference existed between cover at natal dens and areas subsequent to leaving, with new sites consisting of high shrub cover. Herbaceous cover may provide important shelter for river otter young in open canopy habitats, especially at maternal dens where age, mobility, and independence of young increases, potentially exposing them to predation risk. However, our maternal den site may have been primarily selected due to the uniqueness of the anthropogenic denning structure and its subsequent protections, with vegetative cover being a potentially indirect but additional benefit. 


\section{Proximity to Rearing Habitat}

As energetic costs and caloric demands of young increase throughout development, reproductive females may be influenced to relocate to maternal denning sites near high forage resources. Previous reports noted relocations from natal to maternal dens between 3 to 8 weeks after parturition (Liers 1951, Melquist and Hornocker 1983, Woolington 1984, Reid et al. 1994). Based on comparative body length and mobility, we estimated the young to be between 6 to 8 weeks (Liers 1951, Lariviere and Walton 1998, Reed-Smith 2012, Smithsonian Institute 2019). As river otter young begin to eat solid food (predominantly aquatic diet i.e. fish, crayfish, etc.) at 9 to 10 weeks, with weaning occurring at around 12 weeks, access to sufficient foraging resources may increase in importance (Liers 1951, Melquist and Hornocker 1983, Dronkert-Egnew 1991, Reed-Smith 2012). For instance, Powell et al. (1997) suggested that female fishers move to new den locations with easier access to abundant prey to limit the time young are left unattended, which coincides with the observed restriction of movements by female river otters with young during the reproductive and following open water seasons (Melquist and Hornocker 1983, Reid et al. 1994). The maternal den site described here likely provided sustained foraging opportunities, based on incidental documentation of river otter, including the female otter's activity and depredation success. As the adjacent pond contains abundant channel catfish, bluegill, green sunfish (Lepomis cyanellus), largemouth bass (Micropterus salmoides), grass carp (Ctenopharyngodon idella), and crappie (Pomoxis spp.), amid other species that river otters are known to consume (Hansen 2003, Crane Trust unpublished data). Additional benefits of locating maternal dens near prey resources include minimizing energy expenditures and lowering the mortality risk of the reproductive female by decreasing overland travel.

Den relocation closer to a stable body of water may also be necessary to develop behavioral skills, such as swimming and hunting. As essential skills for semiaquatic mesocarnivores, river otters need to be taught to swim and hunt (Reed-Smith 2012). These lessons are often brief but lengthen when finer muscle control and greater mobility are exhibited by young (Reed-Smith 2012). Aligning with detected swimming periods of the young otters, lessons increased in time length and distance from the den as young aged (i.e. less than 15 minutes for the first two lessons and around 25 to 30 minutes for the third and fourth lesson in 2019). Reed-Smith (2012) observed this aquatic acclimation beginning around 4 to 5 weeks (day 38) in captivity; however, Liers (1951) noted that young were restricted to the den until about 10 to 12 weeks. Behavior observed by the female and her young falls between Liers (1951) and Reed-Smith (2012) estimations, as young were first detected swimming at around 8 to 10 weeks. Although hunting lessons where the female releases food for young to catch were not observed at our study site (Liers 1951, Reed-Smith 2012), Melquist and Hornocker (1983) found an importance in areas with shallow, still characteristics for young to independently forage, which matches the nearby perennial pond of the female's maternal den. Other explanations of relocation to a maternal den include nearby disturbance, avoidance of parasites or dead young, and outgrowing the natal den (Powell et al. 1997, Green 2017).

\section{Den Reuse}

As river otters generally do not reuse reproductive dens, the documentation of this maternal den being used for two consecutive years denotes a rarely recorded denning behavior (Melquist and Dronkert 1987). This denning behavior raises questions concerning the frequency of its occurrence and reasons for reuse, considering the record of a marked female in Alaska using the same natal den for two consecutive years as well (J. Noll cited in Woolington 1984). The reuse of a reproductive den suggests fidelity to the denning site, which may be explained by availability, convenience, or preferred protection and seclusion related to that den (Melquist and Hornocker 1983). For example, this maternal dens' close location to an abundant source of prey and the stability and security of a metal pipe den structure may have provided advantageous reasons for reuse. Another possible reason for reuse, may be due to its purpose as a maternal den, as exhibited behaviors and stay length (i.e. 3 weeks in 2019; 3.5 weeks in 2020) were relatively consistent during these two consecutive years.

The reuse of this site as a maternal den further displays the importance of a distinction in denning terminology. As it is likely that both natal and maternal den sites serve to balance the protection of young from age-specific threats (i.e. flooding, cold temperatures, etc.) with access to sufficient forage resources to promote healthy development, the preferences related to each den type will seemingly differ with the growth and development of young. From the combination of observations, both den site characteristics and behavior, and a broad reading of the mustelid literature, it appears that maternal dens may have a distinct set of biological functions for river otter young. Therefore, we propose a modified maternal den definition, in relation to river otters, as sites used subsequent to and exclusive of parturition that proceed weaning where females continue to exhibit denning behavior as young are still largely dependent and in the earliest stages of developing motor and survival skills (Magoun and Copeland 1998, Ruggiero et al. 1998, Green 2017). 


\section{Conclusions}

Based on our maternal den observations, the limited literature regarding river otter reproductive denning, and a broad reading of the mustelid literature regarding distinctions between natal and maternal dens we have made some straightforward hypotheses for future research. First, we hypothesize that habitat selection against flood prone areas and conspecific activity centers may be decreased for maternal den sites compared to natal dens. Furthermore, we posit that female otters may demonstrate a stronger preference for proximity to stable bodies of water with abundant food resources concerning maternal compared to natal denning sites. Finally, we suggest that selection for protection from predators may remain relatively constant between natal and maternal dens. Future research should investigate these hypotheses in a wider range of denning contexts. The apparent shifts in preference between natal and maternal den characteristics suggest that each den type may have a biological function tied to a distinct juvenile life stage and spatially situated ecological processes that benefit them. It may be essential for maternal dens to be located adjacent to relatively stable bodies of water with high vegetative cover on the banks to allow for the safe development of motor and life skills under the female otter's guidance (Reed-Smith 2012).

As the Platte River is a braided river with historically highly variable water levels, river otters may abandon these braided areas during high flows in the reproductive season due to a suspected lack of secluded dens $\left(\mathrm{O}^{\prime}\right.$ Brien and Currier 1987, Dronkert-Egnew 1991, Horn et al. 2012). Interestingly, research indicates that river otter site use increases with beaver activity, due in part to the influence beavers have on wetland systems by increasing ponding (LeBlanc et al. 2007, Gallant et al. 2009). Artificial sand and gravel development may artificially mimic this process. In the CPRV, the increase in sand and gravel development, (i.e. expansion of total area occupied by pits by $538 \%$ and total shoreline of pits by $261 \%$; Pauley et al. 2018), has provided more stable, off-channel water sources to serve the habitat needs of river otters at various life stages, including reproduction.

As this report provides a rare description of a maternal den within the Great Plains, the lack of information on river otter's rearing behavior becomes apparent. More information is needed to understand this species' youngrearing behavior throughout their expansive range. Potential areas of research include frequency of use and reuse of maternal dens as well as structural differences between natal and maternal dens, including number of dens used during the reproductive season, entrance size, and thermoregulatory differences. Use of maternal dens by river otters regionally and the impact of maternal dens on behavior, foraging success, and survival of young should be investigated as well, as it may have significant management implications.

Acknowledgements - We thank the Nebraska Academy of Sciences and the Nebraska Environmental Trust for administering and funding the AXIS P5534-E portable live-streaming camera (Project Number 18-03-4P). We thank Jacob Salter and Patty for first detecting the river otters, Bethany Ostrom and Aurora Fowler for helping collect information at the den site, and Emma Flynn for offering access to publications. We also want to thank Johanna DeStefano for supporting this project via the Lila O. Wilson Biological Monitoring Internship and Gary and Cassandra Pietrok for their support of our staffing needs.

\section{Literature Cited}

Bateman HL, Bond JB, Campbell M, Barrie M, Riggs G, Snyder B, and Swanson WF. (2009) Characterization of basal seminal traits and reproductive endocrine profiles in North American River Otters and Asian Small-Clawed Otters. Zoo Biology 28: 107-126.

Bieber NR, Wilson SP, and Allen CR. (2018) River Otter distribution in Nebraska. Wildlife Society Bulletin 42(1): 136-143.

Biscof R. (2006) Status of the Northern River Otter in Nebraska. The Prairie Naturalist 35: 117-120.

Boyle S. (2006) North American River Otter (Lontra canadensis): A Technical Conservation Assessment. USDA Forest Service, Rocky Mountain Region, Species Conservation Project, Montrose, CO, $56 \mathrm{pp}$.

Brei J, and Bishop AA. (2008) Platte River vegetation mapping project 2005 land cover methods summary. Platte River Recovery Implementation Program Report. Great Plains GIS Partnership, Grand Island, NE, 12 pp.

Currier PJ and Henszey RJ. (1996) Platte River Wet Meadows: A Primer on their Flora, Fauna, Hydrology, Management, and Restoration. Technical Report, U.S. Fish and Wildlife Service (Project No. 14-16-0006-90-917), Grand Island, NE, 25 pp.

Daubenmire RF. (1959) A canopy-coverage method of vegetational analysis. Northwest Science 33: 43-64.

Dronkert-Egnew AE. (1991) River otter population status and habitat use in Northwestern Montana. MS Thesis, University of Montana-Missoula.

Durbin LS. (1996) Some changes in the habitat use of a freeranging female otter Lutra lutra during breeding. Journal of Zoology 240: 761-764.

Farney JP and Jones JK Jr. (1978) Recent records of the river otter from Nebraska. Transactions of the Kansas Academy of Sciences 81: 275-276.

Gallant D, Vasseur L, Dumond M, Tremblay E, and Berube CH. (2009) Habitat selection by river otters (Lontra canadensis) under contrasting land-use regimes. Canadian Journal of Zoology 87(5): 422-432.

Gorman TA, Erb JD, McMillan BR, Martin DJ and Homyack JA. (2006) Site characteristics of River Otter (Lontra canadensis) natal dens in Minnesota. The American Midland Naturalist 156: 109-117. 
Green RE. (2017) Reproductive ecology of the fisher in the southern Sierra Nevada: an assessment of reproductive parameters and forest habitat used by denning females. PhD. Dissertation, University of California-Davis.

Hansen H. (2003) Food habits of the North American River Otter (Lontra canadensis). Department of Zoology and Physiology, University of Wyoming, Laramie, WY, 7 pp.

Horn JD, Joeckel RM, and Fielding CR. (2012) Progressive abandonment and planform changes of the central Platte River in Nebraska, central USA, over historical timeframes. Geomorphology 139: 372-83.

Jenkins D and Burrows GO. (1980) Ecology of Otters in Northern Scotland III. Journal of Animal Ecology 49(3): 755-774.

Jones JK Jr. (1964) Distribution and taxonomy of mammals of Nebraska. University of Kansas Publications, Museum of Natural History 16: 296-299.

Kamler JF and Ballard WB. (2006) Canid diversity in the Texas Panhandle. The Southwestern Naturalist 51(4): 569-572.

Kaul RB, Sutherland D, and Rolfsmeier S. (2006) The flora of Nebraska. School of Natural Resources, University of Nebraska, Lincoln, NE, 967 pp.

Larivière S and Walton LR. (1998) Lontra canadensis. Mammalian Species 587: 1-8.

Liers EE. 1951. Notes on the river otter (Lutra canadensis). Journal of Mammalogy 32: 1-9.

LeBlanc FA, Gallant D, Vasseur L, and Leger L. (2007) Unequal summer use of beaver ponds by river otters: influence of beaver activity, pond size, and vegetation cover. Canadian Journal of Zoology 85: 774-782.

Magoun AJ and Copeland JP. (1998) Characteristics of wolverine reproductive den sites. The Journal of Wildlife Management 62(4): 1313-1320.

Melquist WE and Hornocker MG. (1983) Ecology of river otters in west central Idaho. Wildlife Monograph 83: 1-60.

Melquist WE and Dronkert AE. (1987) River otter. In: M. Novak, J.A. Baker, M.E. Obbard and B. Malloch (Editor), Wild Furbearer Management and Conservation in North America, pp. 625-641. (Ontario Trappers Association, North Bay, Ontario, Canada).

O'Brien JS and Currier PJ. (1987) Platte River channel morphology and riparian vegetation changes in the Big Bend Reach and minimum streamflow criteria for channel maintenance. Platte River Whooping Crane Critical Habitat Maintenance Trust, Grand Island, NE. 48 pp.

Panella MJ and Wilson SP. (2018) Delisting Proposal for North American River Otter (Lontra canadensis) in Nebraska. Nebraska Game and Parks Commission. Lincoln, NE.

Pauley NM, Harner MJ, Brinley Buckley EM, Burger PR, and Geluso K. (2018) Spatial analysis of borrow pits along the Platte River in south-central Nebraska, USA, in 1957 and 2016. Transactions of the Nebraska Academy of Sciences 38: 36-46.
Pikora S. 2016. Topography and water stability preferences for den selection by the North American River Otter (Lontra canadensis). M.S. Thesis, Western Illinois University.

Powell SM, York EC, Scanlon JJ, and Fuller TK. (1997) Fisher maternal den sites in central New England. In G. Prouix, H.N. Bryant and P.M. Woodward (Editor), Martes: taxonomy, ecology, techniques, and management, pp. 265-278. (Provincial Museum of Alberta, Edmonton, Alberta, Canada)

Reed-Smith J. (2012) North American river otter husbandry notebook ( $4^{\text {th }}$ edition). Retrieved from the Internet 15 March 2019: otterspecialistgroup.org.

Reid DG, Code TE, Reid ACH, and Herrero SM. (1994) Spacing, movements, and habitat selection of the river otter in boreal Alberta. Canadian Journal of Zoology 72:1314-1324.

Ruggiero LF, Pearson E, and Henry SE. (1998) Characteristics of American Marten Den Sites in Wyoming. The Journal of Wildlife Management 62(2): 663-673.

Schneider R, Fritz M, Jorgensen J, Schainost S, Simpson R, Steinauer G, and Rothe-Groleau C. (2018) Revision of the Tier 1 and 2 Lists of Species of Greatest Conservation Need: A Supplement to the Nebraska Natural Legacy Project State Wildlife Action Plan. The Nebraska Game and Parks Commission, Lincoln, NE, 101 pp.

[Smithsonian] Smithsonian's National Zoo and Conservation Biology Institute. (2019) Washington, DC: New at the Zoo: North American River Otter Pups. Retrieved from the Internet 5 April 2019: https://nationalzoo.si.edu/animals/ news/new-zoo-north-american-river-otter-pups

Symstad AJ, Wienk CL, and Thorstenson AD. (2008) Precision, repeatability, and efficiency of two canopy-cover estimate methods in northern Great Plains vegetation. Rangeland Ecology \& Management 61: 419-429.

Tiner RW. (2016) Wetland indicators: a guide to wetland formation, identification, delineation, classification, and mapping. (Boca Raton, FL: CRC Press).

USDA-NRCS, United States Department of Agriculture-Natural Resources Conservation Service, Soil Survey Division. (2019) Web Soil Survey. Retrieved from the Internet 15 Apr 2008: http://websoilsurvey.nrcs.usda.gov/.

U.S. Geological Survey. (2016) National Water Information System data available on the World Wide Web (USGS Water Data for the Nation). Retrieved from the Internet 7 Jan 2020: https://waterdata.usgs.gov/nwis/

Wilson SP. (2012) River Otter (Lontra canadensis) Home Range, Habitat Use, Overnight Movement, and Survival in the Platte River of Nebraska. M.S. Thesis. University of Nebraska.

Weast RC. (1972) Handbook of Chemistry and Physics 53rd ed.(Cleveland: Chemical Rubber Pub).

Woolington JD. (1984) Habitat use and movements of river otters at Kelp Bay, Baranof Island, Alaska. M.S. Thesis. University of Alaska Fairbanks. 